\title{
12. A STUDY OF INTERPILLOW LIMESTONES FROM THE $M$-ZERO ANOMALY, DEEP SEA DRILLING PROJECT LEG 51, HOLE 417D
}

\author{
Judith A. McKenzie and Kerry R. Kelts,${ }^{1}$ Geology Institute, Swiss Federal Institute of Technology, Zürich, Switzerland
}

\begin{abstract}
In this paper, we have related isotopic values for limestones filling the interpillow spaces in Cretaceous basalts from Hole 417D to petrographic texture rather than stratigraphic position. Samples were separated into seven categories of progressive recrystallization of pelagic oozes or secondary calcite development. Scanning electron microscope analysis confirms occurrence of some relict nannofossils. Two stages of calcite formation are suggested by isotopic groupings. Lower-level neomorphic transformations of pelagic ooze have $\delta^{18} \mathrm{O}$ ratios of about 0 to -1 per mil PDB and $\delta^{13} \mathrm{C}$ ratios of about +2 to +3 per mil PDB, indicating nearnormal, bottom-sea-water sources. Some coarsely crystalline calcites, in association with altered glass rinds, have $\delta^{18} \mathrm{O}$ ratios between -4 and -5 per mil PDB. We suggest that early rift-valley pillow flows plunged into ponded carbonate oozes. These oozes quickly recrystallized to hinder circulation and help preserve some Cretaceous basaltic glass.
\end{abstract}

\section{INTRODUCTION}

On Leg 51 we recovered interpillow limestones from the upper part of the basalt section cored at Hole 417D. Their presence seems directly responsible for the preservation of almost-fresh glass in some pillow margins. Fresh basalt glass has rarely been found in basalt as old as Middle Cretaceous. Indeed, observations suggest that palagonitization and devitrification of pillows proceed at an average rate of 1 $\mathrm{mm} / \mathrm{y}$ (Moore, 1966). On the other hand, completely altered basaltic glass of the same age but without interpillow limestones was cored from Hole $417 \mathrm{~A}$, which is only 400 meters from Hole 417D. The existence of interpillow limestones appears to be dependent upon the site's original position within the ancient mid-ocean rift complex (Figure 1). Hole 417A was situated over a buried basement high, whereas Hole $417 \mathrm{D}$ was in a depression that probably contained ponded, pelagic carbonates.

The object of this study was to combine petrographic and stable-isotope observations, in order to:

1) determine whether the interpillow limestones were derived from pelagic oozes;

2) examine the role of the limestones in the preservation of fresh glass;

3) evaluate evidence for early lithification;

4) determine whether hydrothermal systems might have caused the limestone formation; and

5) compare possible thermal processes with low-temperature ones.

\section{SAMPLE DESCRIPTIONS}

The sedimentary section at Hole 417D consists mainly of pelagic sediments. A stratigraphic comparison of Hole

\footnotetext{
${ }^{1}$ Present address: Scripps Institution of Oceanography, Deep Sea Drilling Project, Mail Code A-031, La Jolla, California 92093.
}

417A with Hole 417D (Figure 1b) and seismic evidence indicate that Hole 417D was probably the locus of carbonate ooze sedimentation or ponding along an early Aptian ridge system. The dark-gray, soft nannofossil chalks from early Aptian times appear to overlie pillow basalts conformably. Although there is evidence of dissolution, coccoliths from these chalks are well preserved and show only moderate calcite overgrowth. The lack of significant diagenesis could be explained by the limited amount of overburden $(343 \mathrm{~m}$ ) at the site (Schlanger and Douglas, 1974). Pillow basalts from both Hole 417A (Dandini Hill) and Hole 417D are part of the $M 0$ magnetic anomaly, suggesting that the basalt section is not significantly older than the overlying chalks (Bleil and Smith, this volume).

Interpillow limestones were encountered in Hole 417D basalt Cores 22, 26, 27, 28, 29, 30, and 31 (Figure 2). They occur over a range from a few centimeters to 70 meters below the sediment/basalt contact. Cores 417D-32 through 34 penetrated a thick, massive basalt (flow unit 3), which may have formed the floor of a depression in the ancient mid-ocean rift complex. Below this flow unit, no further interpillow limestones or sedimentary interbeds were observed. It is uncertain whether the chemically similar pillow piles above flow unit 3 , which were subdivided into flow units $1 \mathrm{a}, \mathrm{b}, \mathrm{c}$, and 2 , do in fact belong to separate or synchronous eruptions. These upper flow units were partly defined by assuming that the limestones were interbeds. With the exception of one $20-\mathrm{cm}$ bed containing horizontal bedding (Interval 417D-28-5, 0 to $20 \mathrm{~cm}$ ), all of the samples are clearly cavity fillings in a pillow pile. It is uncertain whether this infilling was the result of carbonate oozes caught up into moving lava flows, or of later sifting in of pelagic carbonate from above. Clear geopetal indicators are rare. In most occurrences, as shown in Figure 3, limestone completely fills cavities, even as thin wedges along intact glassy margins. Sedimentary structures are also irregularly in- 

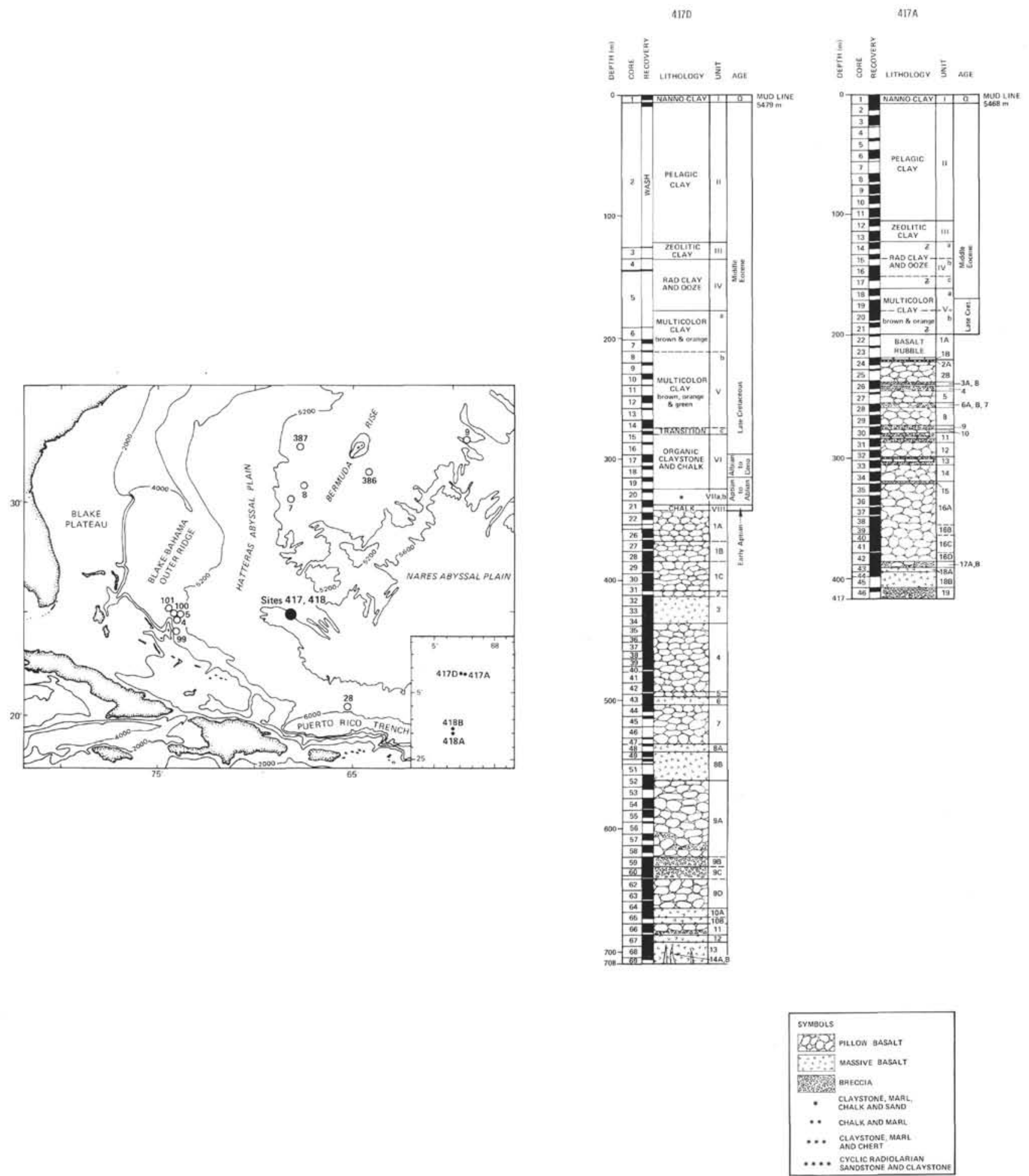

Figure 1. Location of Sites 417 and 418, Legs 51 through 53 and the generalized stratigraphy of sediment and basalt sections from Holes $417 A$ and $417 D$.

clined. Laminations defined by small pillow fragments generally spalled glass shards - commonly tend to follow pillow contours. On the basis of these structures, we suggest that, with the possible exception of the thicker, fine-grained bed of limestone in Interval 417D-28-5, 0 to $20 \mathrm{~cm}$ (which has sub-horizontal laminations), the limestones may not represent significant interruptions in the outpouring of volcanic effusives.

The macroscopic description of the samples is given in Table 1. Interpillow limestones, as treated in this paper, exclude obvious secondary calcite vein filling in pillow fractures. Various types of limestone were recovered. All are 


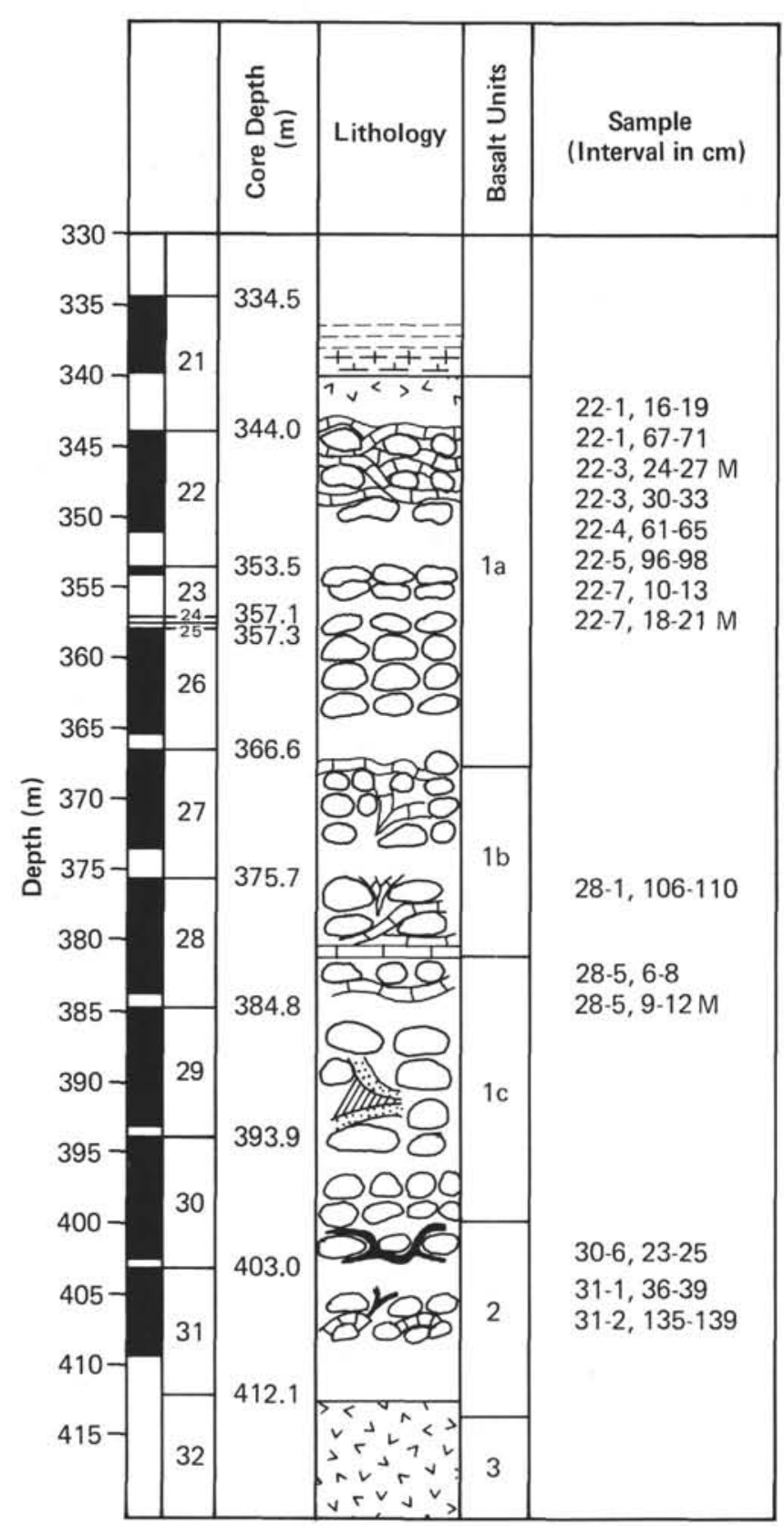

Figure 2. Detailed stratigraphy of the basal sediment and upper basalt section from Hole $417 \mathrm{D}$, indicating sample locations and presence of interpillow limestones.

compact and hard, and most are shades of green. A zonal color change is commonly observed in some of the limestone samples as a function of distance from a pillow margin. For example, in Sample 417D-22-3, 30 to $33 \mathrm{~cm}$ along the pillow margin, the limestone is dark green to greenish black, suggestive of a chilled margin. Gradually, within $1 \mathrm{~cm}$, colors change from light green to gray to pinkish hues (Figure 4). The color zones are crossed by groups, stringers, and rows of small volcanogenic fragments.

A few specimens (e.g., Sample 417D-28-4, 2 to $13 \mathrm{~cm}$, Figure 5) show a transition from coarsely recrystallized limestone to calcite fracture fillings. Brecciated glassy mar- gins and angular pillow fragments float in a white matrix of coarse spar, which appears to have a later, secondary origin. Faint sedimentary fabrics occur in most of the limestone samples, but some interpillow limestones show no observable sedimentary structures and may not be derived from sediment recrystallization. These samples of non-sedimentary origin have several characteristics in common. They tend to be either more yellowish or brightly colored. Also, $\mathrm{X}$-ray diffraction analysis (Table 1) shows that, while all the obvious sedimentary limestones contain variable amounts of both calcite and quartz, the other samples are composed of calcite only.

The first limestone encountered in Hole 417D (Interval $22-1,0$ to $20 \mathrm{~cm}$ ) was located just below the sediment/basalt contact, although coring procedures and recovery may shift its position up to 6 meters. Whether this limestone, shown in Figure 6, derives from pelagic sediments is uncertain. Vibrantly colored swirls of blue-green, green, and yellow limestone containing smectite are mixed with patches of drusy calcite cement and highly altered basalt fragments. Glassy pillow selvages have been stripped and incorporated into a calcite matrix. A similar, brightly colored limestone containing chlorite was noted at the basalt contact in Hole 386 during Leg 43 (Tucholke, Vogt, et al., 1979). Hole 386 was drilled into crust the same age as the cores from Hole 417D on the $M 0$ anomaly (see Figure 1). The forementioned authors suggest that the limestone was formed as a result of a nearby hydrothermal vent, which also expelled native sulfur and caused the radiating color halos around fragments. Another explanation for this phenomenon could be related to euxinic events during the Albian to Aptian (Ryan and Cita, 1977). Perhaps, the exposure of the fresh pillows to anoxic bottom waters accelerated alteration of the glass. Reduced iron and manganese are mobile and could have contributed to the formation of vividly colored clay minerals from the devitrified glass. Protective hydroxide coatings would not form on altered mineral grains.

\section{PETROGRAPHY}

The interpillow limestones recovered from Hole 417D differ petrographically from some other reported deep-sea occurrences (e.g., Garrison et al., 1973; Bonatti et al., 1974; and Bernoulli et al., 1978). The original microfossil tests in the samples from Hole 417D have not been preserved by cementation, as reported for limestones in the papers cited, but have generally been completely recrystallized. Examination of smear slides revealed traces of scattered, poorly preserved nannofossil relicts which were also seen in SEM micrographs (e.g., Plate 1 and Figure 7). The extent of recrystallization is surprising, in view of its absence in the overlying nannofossil chalks.

Most samples show evidence of a pelagic origin. These pelagic oozes have petrographic textures that indicate varying degrees of neomorphic development. The extent of this development is however not depth-dependent, but is rather closely related to the absolute distance from the nearest pillow margin. In most cases over 1 to $2 \mathrm{~cm}$ from a margin, limestones are more likely to retain original features. These include numerous spheroid blebs, which are filled with either silica or calcite. They are interpreted as relict radiolar- 


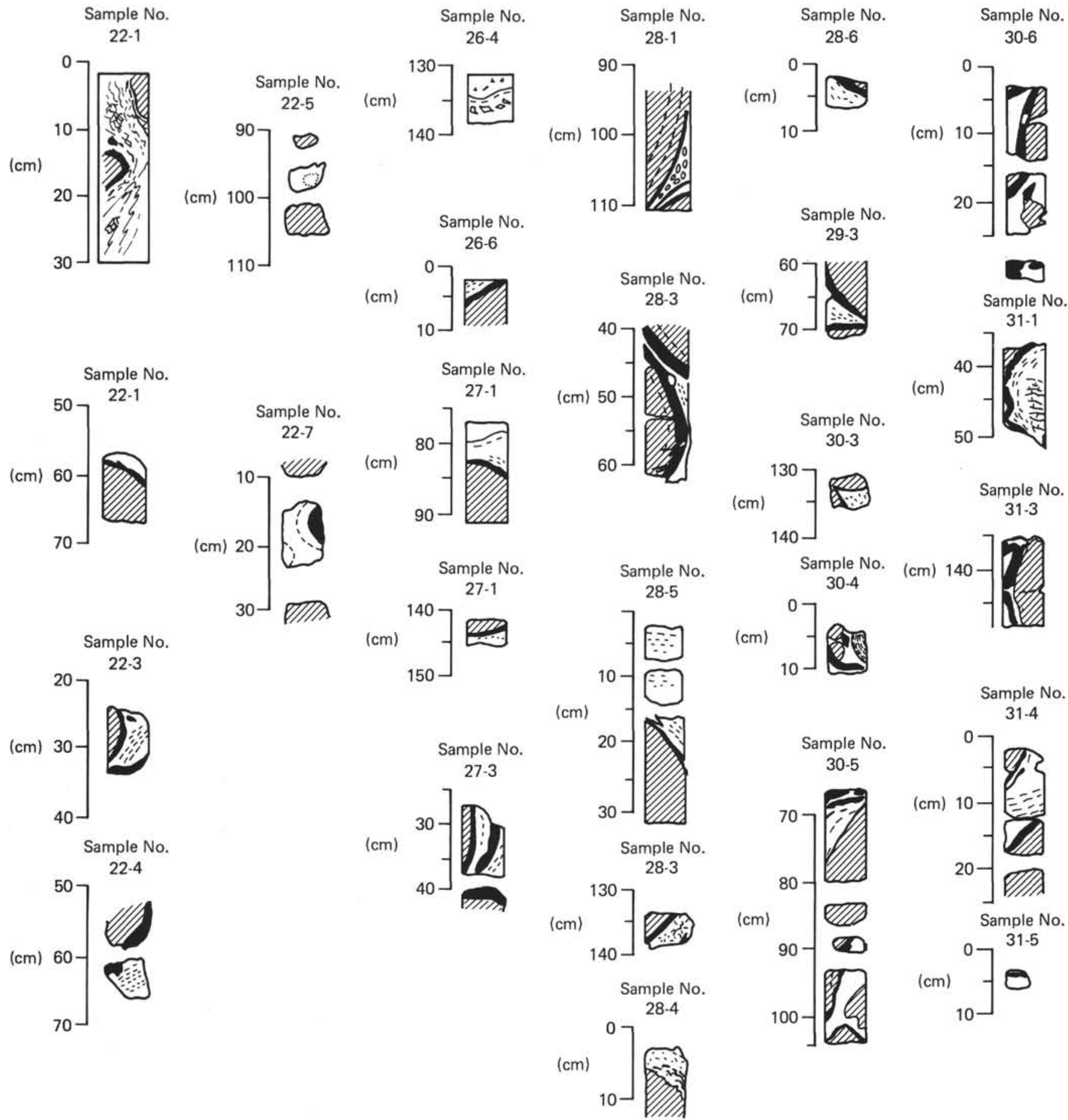

Figure 3. Graphical summary of the occurrences of interpillow limestones recovered from Hole 417D.

ian or foraminiferal molds, although wall structures have been obliterated. There is also a relationship which parallels the extent of glass alteration. Coarse sparite commonly accompanies extensively altered glass, while fresh-looking glass shards are common in fine microcrystalline limestones.

The calcite in the interpillow limestones may be considered neomorphic calcite. In other words, the limestones are not merely the result of cementation but an entire recrystallization. Older nannofossils and micrite have been gradually consumed and simultaneously replaced by new calcite crystals. In general, there has been an in situ ionic transformation of sedimentary calcite into interlocking crystalline calcite.

In accordance with the scheme of Bathurst (1975), some of the Hole 417D interpillow limestones show agrading neomorphism; i.e., a mosaic of finely crystalline carbonate is replaced by a coarser sparry calcite. This is a combination of polymorphic transformations and recrystallization. The texture of this agrading neomorphism increases towards pillow margins. A coarse sparry layer of anhedral calcite crystals lines the glassy rind. Crystal grain size decreases for 
TABLE 1

Description of Interpillow Limestone Samples from Hole 417D and Comparative Samples

\begin{tabular}{|c|c|c|c|c|}
\hline \multirow{2}{*}{$\begin{array}{c}\text { Sample } \\
\text { (Interval in } \mathrm{cm} \text { ) }\end{array}$} & \multicolumn{2}{|c|}{ XRD } & \multirow{2}{*}{$\begin{array}{l}\text { Recrystallization } \\
\text { Index }\end{array}$} & \multirow[b]{2}{*}{ Description } \\
\hline & Calcite & Quartz & & \\
\hline $21-4,26-28$ & +++ & tr. & R0 & $\begin{array}{l}\text { Medium-gray, soft nannofossil chalk. Early Aptian age. Directly overlies } \\
\text { basalt. Nannofossil preservation moderate, rare overgrowths. }\end{array}$ \\
\hline $22-1,16-17$ & +++ & - & R6 & $\begin{array}{l}\text { First pillow-margin limestone encountered. Bright green, blue-green, } \\
\text { yellow and creamy sparry limestone. Patches of large, clear, blocky calcite. } \\
\text { Replacement of altered glass rind. }\end{array}$ \\
\hline $22-1,22-24$ & & & R6 & $\begin{array}{l}\text { As above: brightly colored bluish green to yellow limestone along a } \\
\text { pillow margin. Patches of blocky calcite. Clay clots. }\end{array}$ \\
\hline $22-1,67-71$ & & & R4, R5 & $\begin{array}{l}\text { Light yellow to green limestone along an altered pillow margin, with } \\
\text { scattered breccia fragments of volcanic glass. }\end{array}$ \\
\hline $22-3,24-27$ & +++ & + & $\mathrm{R} 2, \mathrm{R} 3$ & $\begin{array}{l}\text { Fine-grained, light greenish gray limestone with volcanic bits scattered in } \\
\text { vague laminae. Away from margin, color grades to a pink hue. }\end{array}$ \\
\hline $22-2,30-33$ & & & $\mathrm{R} 2, \mathrm{R} 3$ & $\begin{array}{l}\text { Fine-grained, light greenish gray limestone matrix with scattered volcanic } \\
\text { shards in vague laminae. } 1 \mathrm{~cm} \text { away from glassy margin, color grades to a } \\
\text { pink hue. }\end{array}$ \\
\hline $22-4,61-65$ & +++ & + & $\mathrm{R} 2$ & $\begin{array}{l}\text { Light olive-green to brown, fine-grained limestone. Flow structures and } \\
\text { laminations with sand-sized pillow fragments. Many patches with coarser } \\
\text { calcite. }\end{array}$ \\
\hline $22-5,96-98$ & +++ & + & $\mathrm{R} 1$ & $\begin{array}{l}\text { Very fine-grained, homogeneous, greenish yellow limestone sprinkled with } \\
\text { tiny bits of basalt glass. White blocky calcite vein at margin. }\end{array}$ \\
\hline $22-7,10-13$ & +++ & + & $\mathrm{R} 3, \mathrm{R} 4$ & $\begin{array}{l}\text { Light green to light greenish gray limestone with sand-size pillow fragments } \\
\text { defining flow banding. Green clots of altered glass. X-ray mineralogy } \\
\text { includes mixed-layer clay and traces of zeolite. }\end{array}$ \\
\hline $22-7,18-21(\mathrm{M})$ & ++ & +++ & R5 (R7) & $\begin{array}{l}\text { Hard, moderately coarse grained, green limestone with scatered volcano- } \\
\text { genics. (A thin coarsed calcite vein crosses the upper margin.) }\end{array}$ \\
\hline $28-1,106-110$ & +++ & - & R7 & $\begin{array}{l}\text { Yellowish gray, coarse-grained "wormy" (vermicular) calcite within an } \\
\text { altered pillow margin. }\end{array}$ \\
\hline $28-5,6-8$ & +++ & ++ & $\mathrm{R} 1$ & $\begin{array}{l}\text { Very fine grained, hard, homogeneous, greenish gray limestone with rare, } \\
\text { scattered volcanic bits defining current structures and layering. }\end{array}$ \\
\hline $28-5,9-12(\mathrm{M})$ & ++ & + & R4 & $\begin{array}{l}\text { Light to medium green, fine-grained, compact limestone with vague } \\
\text { current layering by scattered pillow fragments. }\end{array}$ \\
\hline $30-6,23-25$ & +++ & + & R4, R5 & Fine-grained, olive-gray, homogeneous limestone with rare volcanogenics. \\
\hline $31-1,36-39$ & ++ & + & $\mathrm{R} 1, \mathrm{R} 2, \mathrm{R} 3$ & $\begin{array}{l}\text { Fine-grained, light olive-gray limestone with angular sand-size pillow frag- } \\
\text { ments strewn along a glassy margin. } 1.5 \mathrm{~cm} \text { from this margin, color of the } \\
\text { limestone grades to a pink hue. }\end{array}$ \\
\hline $31-2,135-139$ & ++ & - & R6 & Coarse, sparry calcite with some drusy vugs located in a pillow margin. \\
\hline \multicolumn{5}{|l|}{ Comparative Samples } \\
\hline $417 \mathrm{~A}-46-3,11-15$ & +++ & None & R7 & $\begin{array}{l}\text { Large scalenohedral calcite crystals growing individually as a secondary } \\
\text { replacement in an altered glassy margin. Used as representative of a non- } \\
\text { sediment source. }\end{array}$ \\
\hline $\begin{array}{l}\text { 313A-3-1, 125-128 } \\
\quad(\text { Leg 42A) }\end{array}$ & & & & $\begin{array}{l}\text { Breccia of altered basalt clasts cemented by a coarse nannofossil-foraminites } \\
\text { limestone. Used as a comparison to early deep sea lithification (Bernoulli } \\
\text { et al., 1978). }\end{array}$ \\
\hline GRL-1 & +++ & + & & $\begin{array}{l}\text { Comparable sample of Upper Jurassic interpillow pelagic limestone from } \\
\text { an ophiolite suite of the Othris Zone near Neraida, Greece. Fine-grained, } \\
\text { reddish limestone with coarse mosaic of white calcite lining pillow margins. }\end{array}$ \\
\hline
\end{tabular}

Note: $++++=$ exclusively,$+++=$ dominant,$++=$ common $;+=$ minor $;-=$ faint trace $(M)=$ sample from magnetics.

${ }^{a}$ See Table 2.

about 1 to $2 \mathrm{~cm}$ from the pillow margin, and relict patches of micrite with microfossil molds are commonly enclosed in the calcite spar.

The mechanism of agrading neomorphic transformations in deep-sea sediments remains poorly understood. One question concerns the volume discrepancy. How does an original coccolith ooze recrystallize without forming cavities? Clearly there is a net transport of calcium into the lithified sediment. In most of the textural states examined in this study, cement was difficult to separate from neomorphic spar unless a gradational or progressive contact existed. Neomorphic spar begins to form once the sediment is partly consolidated (Bathurst, 1975). Relict evidence of original tests and micrograph textures suggests that the microfossils were already replaced prior to sparification. The passage from micrite to microspar is evidenced by the 


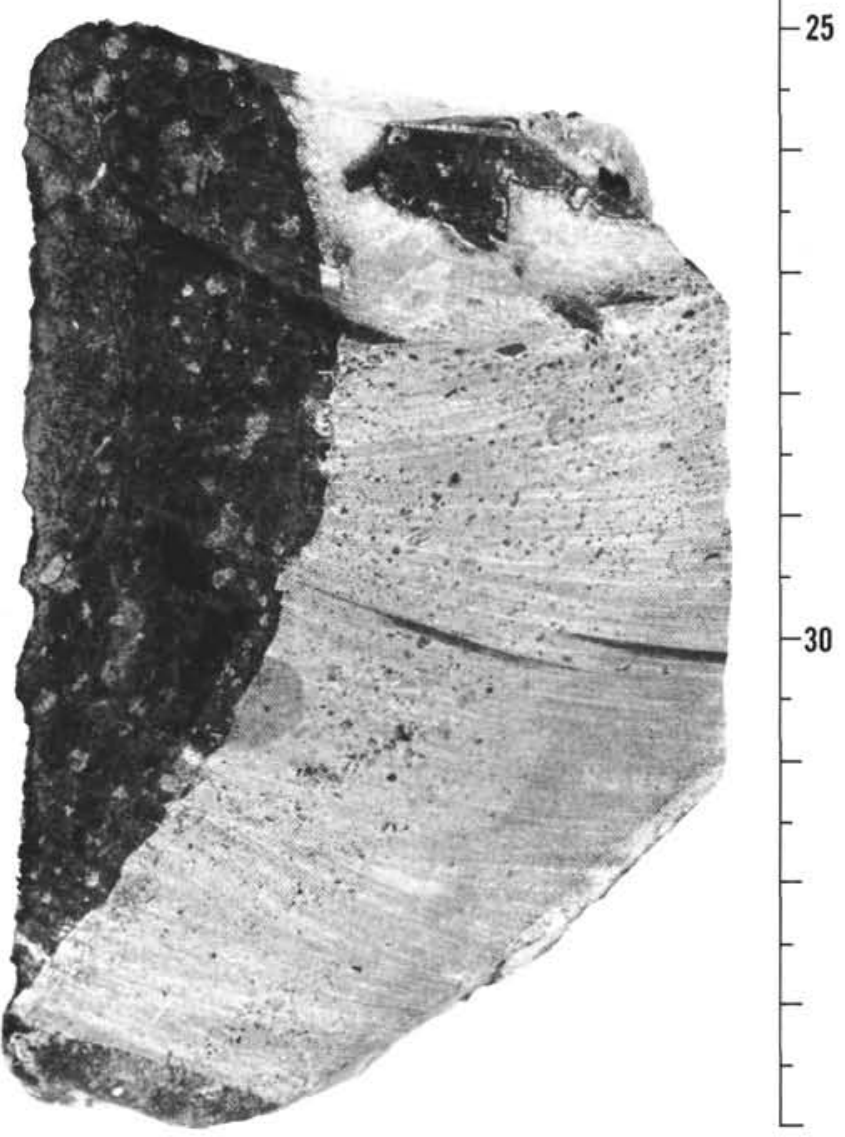

Figure 4. Example of typical, recrystallized interpillow pelagic carbonates along a glassy pillow margin: Sample 417D-22-3, 25-34 cm (Piece No. 3). Subparallel bedding outlined by sand-size fragments from pillows. The extent of recrystallization decreases outward from the pillow margin, changing from a light green, neomorphic spar (R4) to fine-grained, pinkish micrite with relict microfossils (R2) to the lower right. At the top are zones of coarse, neomorphic spar (R5). Basalt glass remains freshlooking.

"structure grumeleuse" textures in clotted limestone from R3-stage development, as will be discussed later.

\section{RECRYSTALLIZATION}

We have used macroscopic and thin-section textures to separate samples according to an arbitrary recrystallization index, ranging from $\mathrm{R} 0$ to $\mathrm{R} 7$. The scale and criteria of recognition are given in Table 2. Several recrystallization stages may occur together in the same sample or thin section. In Table 3, the stable-isotope results are keyed to the dominant stage observed in the samples measured. None of the limestone samples exhibited in the initial stage $\mathrm{R} 0$ other than the overlying chalks and a comparable specimen (Sample $313 \mathrm{~A}-3-1,125-128 \mathrm{~cm}$ ) from Leg 42A (Bernoulli et al., 1978). Examples of the various stages are illustrated in Figures 8 through 14 . Stages R0 to R5 refer to altered sediments, whereas R6 and R7 have a questionable sedimentary origin or are by-products of volcanic alteration. Most sam-

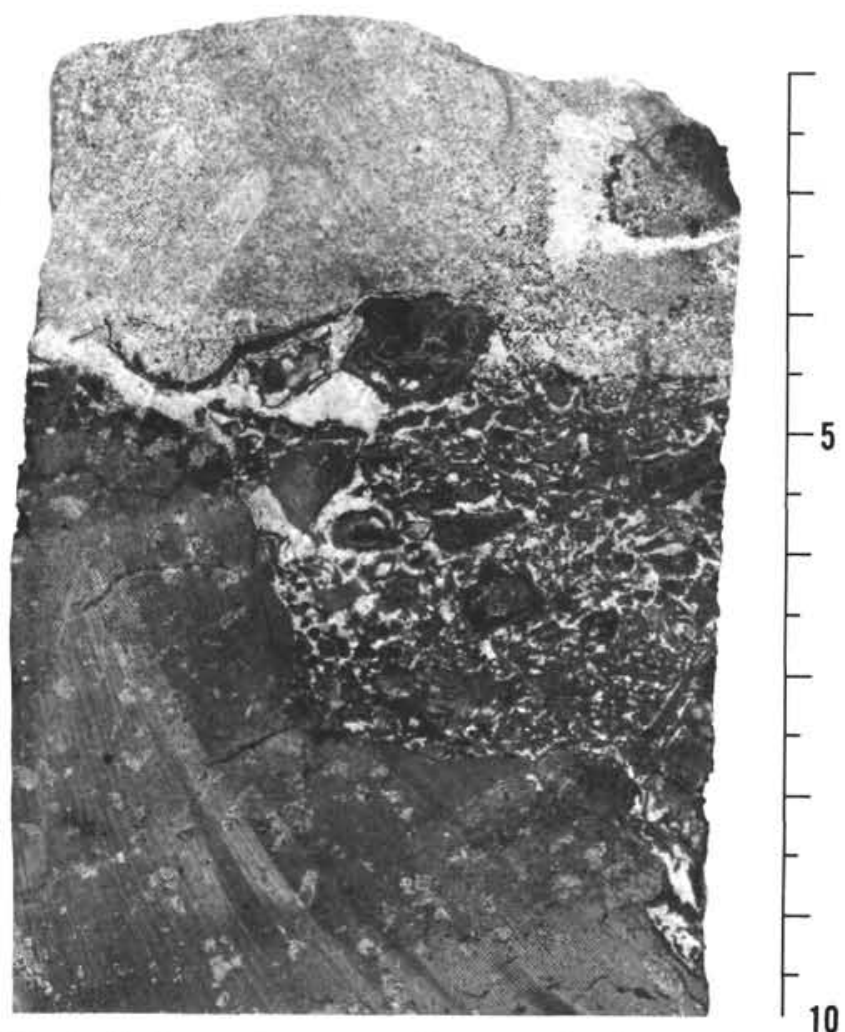

Figure 5. Extensive recrystallization of pelagic carbonates to an equiangular spar (R5) along a pillow and later formation of secondary blocky calcite within an altered glassy margin. Sample 417D-28-4, 2-13 cm (Piece No. 1A).

ples show more than one type but are classed on the basis of the most prevalent character.

\section{R1}

Three specimens (Samples 417D-22-5, 96-98 cm, 417D28-5, 6-8 cm, and 417D-31-1, 36-39 cm) have R-1 stage textures, although each shows gradational changes to higher recrystallization stages toward pillow margins. Each has faint layering and current laminations which are outlined by volcanogenics. Color zones move from green to pink tinges away from the rim. In thin section, a mosaic of micrite-size calcite comprised about 90 per cent of the sample. Radiolarian "'ghosts,"' consisting of spheroid calcite, are scattered and slightly more common near pillow margins. Scattered volcanic glass bits are more angular and remain essentially isotropic. Calcite crystals are coarser near larger green volcanic clasts and sometimes appear to encroach upon the weathering fragments. Occasionally, patches of mosaic calcite occur as scattered, rounded blebs in a microcrystalline matrix.

\section{$\mathbf{R} 2$ to $\mathbf{R} 3$}

Several samples from the first basalt core overlap R2 and R3 stages, including Samples 417D-22-3, 24-27 cm, 417D-22-3, 30-33 cm, 417D-22-4, 61-65 cm, 417D-22-7, $10-13 \mathrm{~cm}$, and again 417D-31-3, 36-39 cm. Micrite clots, some pellet-like and/or containing faint microfossil relicts, are interrupted patches of coarser but still fine-grained sparite. The contact between these two types is obscure and 


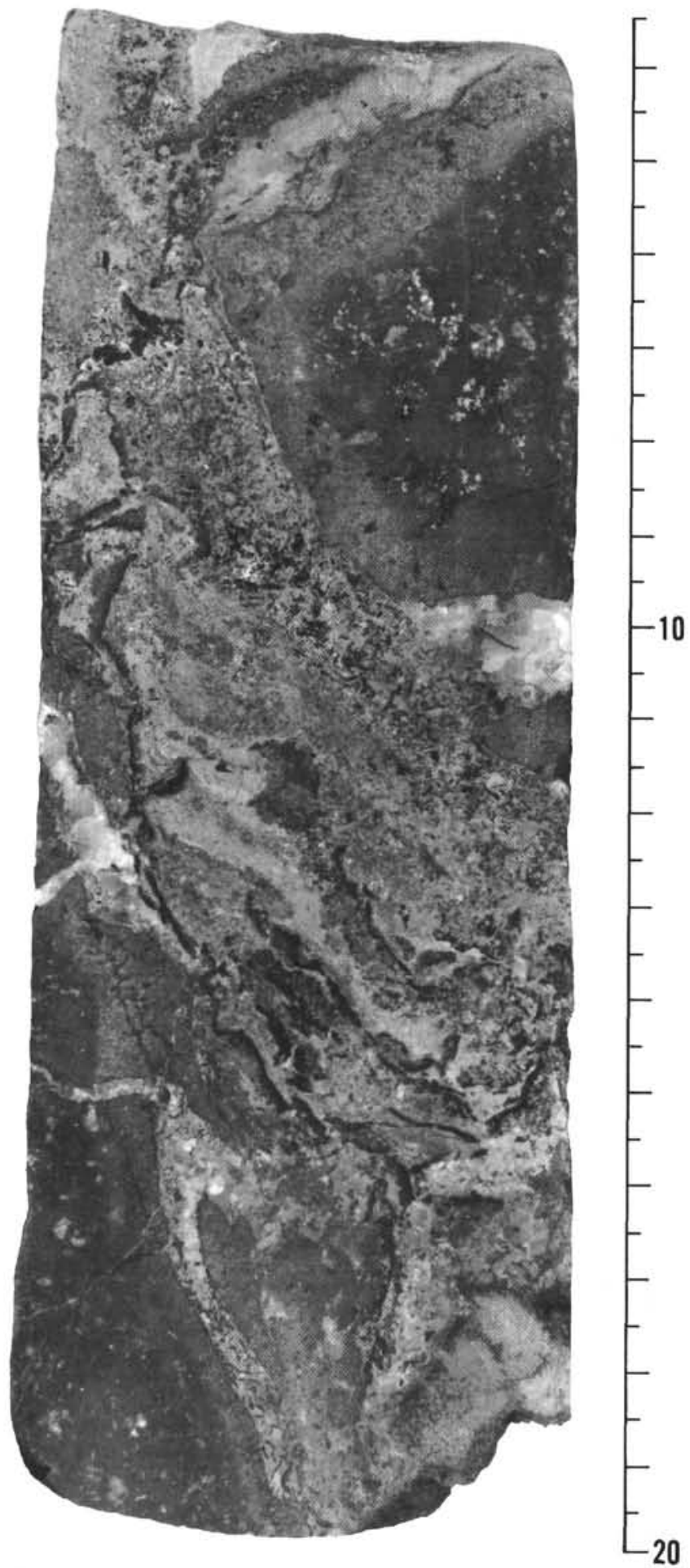

Figure 6. First limestone encountered in the Interval 417D22-1, 3 to $20 \mathrm{~cm}$ (Piece No. 1A). Swirls of bright blue, green-yellow coarse limestone enclose altered fragments from glassy pillow margins. Scattered patches of clear, coarse, blocky calcite spar. Basalt margins with alteration rind. Scale in $\mathrm{cm}$. approximately 50 per cent of the sample remains a mosaic of diffuse rounded clots in R2 stages, but clots float in more than 50 per cent neomorphic spar in R3 stages. Relict microfossil "ghosts" are 0.1 to $0.3 \mathrm{~mm}$ in diameter and may be either silica or calcite. Considerable amounts of a fine-grained isotropic mineral (opal?) interlock with the calcite matrix. Many of the relicts have a sparry center and a micrite rim, which may represent former test walls. Volcanic shards are partly isotropic or show very little alteration. Basaltic glass remains mostly brown. Even in these fine-grained limestones, there is a $0.5-\mathrm{mm}$ band along the glassy pillow margin which has a blocky anhedral mosaic of calcite.

\section{R4 to $\mathbf{R 5}$}

Micrite has completely recrystallized to a mosaic of anhedral, neomorphic spar. The crystal size is less than 0.1 $\mathrm{mm}$ for R4 stages and greater than $0.1 \mathrm{~mm}$ for R5 stages. Relicts have been consumed, but some flow textures and scanning observations still indicate an original pelagic carbonate origin. Microfossil relicts have been obliterated. Samples 417D-22-1, 67-71 cm, 417D-22-7, 18-21 cm, 417D-28-5, 9-12 cm, and 417D-30-6, 23-25 cm are typical examples which cross the R4 to R5 spectrum. The neomorphic matrix is an equiangular spar in which varying abundances of scattered, coarser calcite patches occur. Microcrystalline quartz infills the matrix. Most scattered glass shards are angular, brown, and isotropic, although some are also altered green or yellow. Plagioclases along fractures have calcite cores. The pillow margin is lined by rows of 0.1 -mm-long calcite prisms which change abruptly to the fine mosaics. Grain size decreases away from the margin. Volcanic clasts appear to float in the spar.

\section{R6}

In the brightly colored specimens (Samples 417D-22-1, $16-19 \mathrm{~cm}$ and 417D-22-1, 22-24 cm) and 417D-31-2, $135-$ $139 \mathrm{~cm}$, and along numerous pillow contacts, coarse sparry calcite invades the glassy rind. Drusy calcite is common but quartz is rare to absent. Textures may show large $(0.5$ to $1 \mathrm{~mm}$ ) blocky interlocking mosaics or large crystals with planar boundaries, which poikilitically enclose stringers of green chlorite or altered glass. Single, large crystals occur in microfractures which separate the rind from the pillow margin. Wispy fans of radial calcite occur. Plagioclase crystals along cracks have been mostly replaced by calcite. On the basis of this textural evidence, we consider these carbonates as derived not from pelagic sources but from the alteration of volcanics. They are located in spaces that probably had open communication with circulating waters, as in the case of Core 22, or near the uppermost surface of the basalt/sea water boundary.

\section{R7}

Another unusual form of non-pelagic interpillow carbonate filling was observed in one specimen, Sample 417D$28-1,106-110 \mathrm{~cm}$. Large prismatic crystals line the pillow 

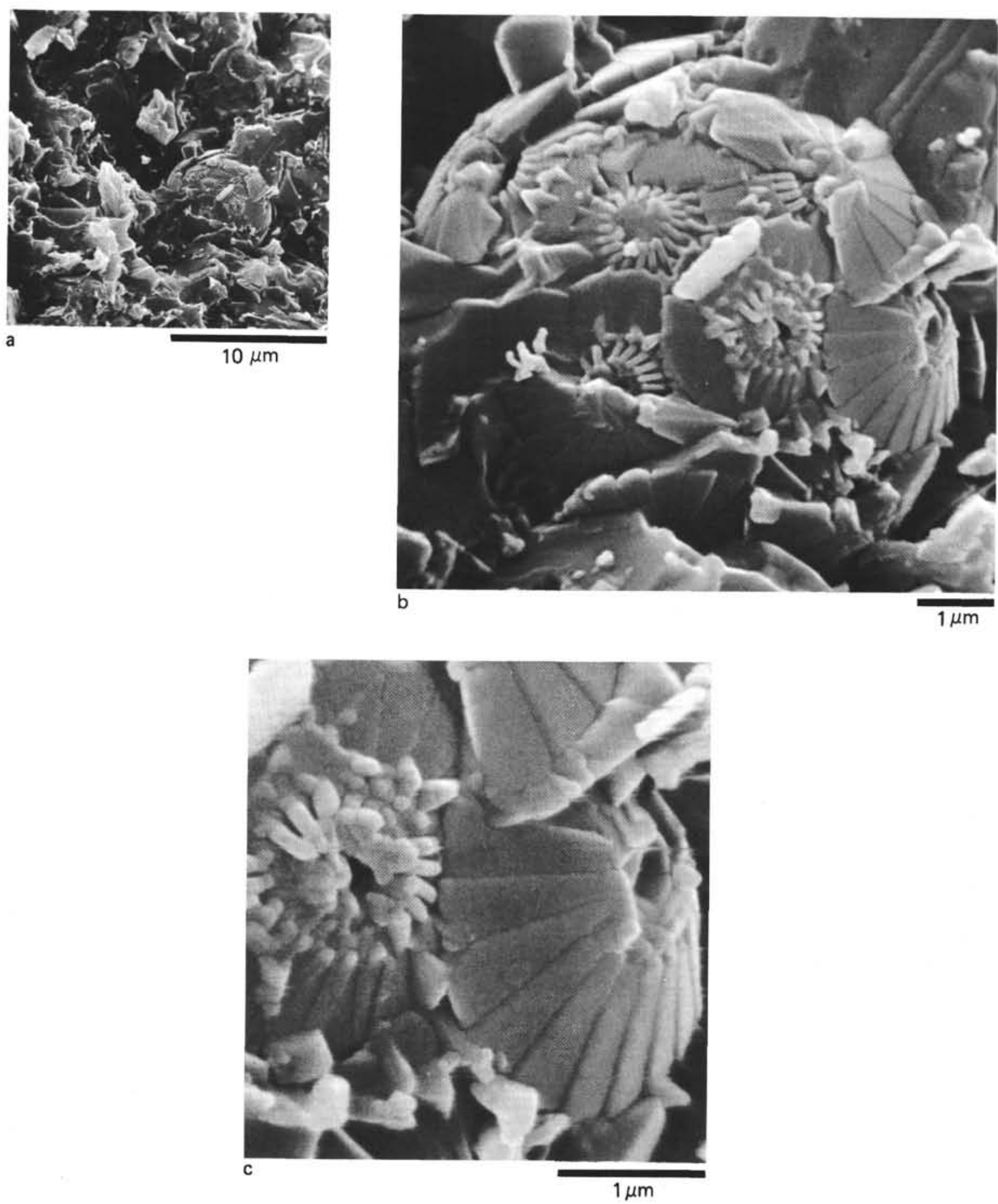

Figure 7. Evidence of sedimentary origin shown by a scanning electron micrograph of a broken surface from the pale-pinkish part of limestone, Sample 417D-31-1, 36-39 cm (Piece No. 2C). (a) Complete coccosphere embedded in an anhedral blocky calcite matrix. (b) Discorhabdus rotarorius. (c) Detail of D. rotatorius coccolith shield.

margin, but vermiform calcite patches are set in the coarse sparry matrix filling the interstices. This texture has been designated "wormy" calcite. In many but not all cross sections, a thin, glassy case, altered to highly birefringent clays, encloses a coarse anhedral mosaic. Along the thinwalled glass margin, crystals have a knobby appearance (Figure 14) which is suggestive of rapid growth or quenching. A similar knobby texture was observed in several crys- tals near a pillow margin from Sample 417D-22-7, 69-71 $\mathrm{cm}$ (Figure 14), but was interblocked in the coarse neomorphic spar (R5 stage) of the limestone. From the lack of cleavage and low birefringence, we came to the conclusion that this occurrence may be an aragonite relict. The end of a calcite worm extends into R3 limestones in Sample 417D$22-7,10-13 \mathrm{~cm}$ and runs along the top of R5 Sample 417D-22-7, $18-21 \mathrm{~cm}$. The calcite worm is sheathed in thin 
TABLE 2

Recrystallization Index: Textural Criteria for the Classification of Interpillow Limestone Samples According to a Relative Scale of Recrystallization, Including Various Stages of Neomorphic Calcite Formation

R0 Unlithified carbonate sediment, soft chalk to limestone. Fossils are preserved in carbonate matrix.

R1 Fine-grained, hard pelagic limestone, uniformly fine micritesize with microfossil relicts or "ghosts."

R2 Micrite clots containing relict microfossils, mosaics of micronsize particles now interrupted by sparry calcite. Micrite is more than 50 per cent.

R3 Micrite clots with microfossil relicts floating in a mosaic of coarser $(10$ to $30 \mu \mathrm{m})$ grained spar with embayed boundaries. Micrite is less than 50 per cent. "Structure grumeleuse" (e.g., Bathurst, 1975).

R4 Completely recrystallized to a fine neomorphic spar mosaic (less than $0.1 \mathrm{~mm}$ ).

R5 Completely recrystallized to a coarse neomorphic spar mosaic of anhedral calcite.

R6 Large crystals of calcite with planar margins poikilitically enclose altered volcanogenic shards or blebs. Plagioclase grains commonly have centers filled with calcite.

R7 Replacements in pillow margins forming "wormy" (vermiform) patches of calcite. Coarse anhedral mosaics commonly show a quench-like, knobby texture abutting against a thin altered glass rind. Possible aragonite textures exist.

TABLE 3

Stable-Isotope Data

\begin{tabular}{|c|c|c|c|c|}
\hline $\begin{array}{c}\text { Sample } \\
\text { (Interval in } \mathrm{cm} \text { ) }\end{array}$ & $\begin{array}{l}\text { Recrystallization } \\
\text { Inde } \mathrm{x}^{\mathrm{a}}\end{array}$ & $\begin{array}{c}{ }^{{ }^{13}} \mathrm{C} \text { PDB } \\
(\% \circ)\end{array}$ & $\begin{array}{c}{ }^{18} \mathrm{OPDB} \\
\% \% 0)\end{array}$ & $\begin{array}{c}\mathrm{T} \\
\left({ }^{\circ} \mathrm{C}\right)\end{array}$ \\
\hline $417 \mathrm{D}-21-4,28-30$ & R0 & +1.55 & -1.97 & 20 \\
\hline $22-1,16-17$ & R6 & -3.28 & -4.92 & 35 \\
\hline $22-1,67-71$ & R4, R5 & +2.64 & -0.78 & 15 \\
\hline $22-3,24-27$ & $\mathrm{R} 2, \mathrm{R} 3$ & +2.76 & -0.33 & 13 \\
\hline $22-3,30-33$ & R2, R3 & +3.63 & -0.21 & 13 \\
\hline $22-3,30-33^{c}$ & $\mathrm{R} 2, \mathrm{R} 3$ & +3.00 & -0.14 & 12 \\
\hline $22-4,61-65$ & R2 & +1.87 & -0.63 & 14 \\
\hline $22-5,96-98$ & R1 & +3.15 & -0.35 & 13 \\
\hline $22-5,96-98^{c}$ & $\mathrm{R} 1$ & +2.08 & -0.59 & 14 \\
\hline $22-7,10-13$ & $\mathrm{R} 3, \mathrm{R} 4$ & +3.77 & -0.33 & 13 \\
\hline $22-7,18-21^{b}$ & $\mathrm{R} 7 / \mathrm{R} 5$ & $+1.81 /+1.90$ & $-4.31 /-3.96$ & 32 \\
\hline $28-1,106-110$ & R7 & +0.75 & -4.06 & 30 \\
\hline $28-1,106-110^{c}$ & R7 & +0.90 & -4.01 & 30 \\
\hline $28-5,6-8$ & R1 & +2.29 & -0.77 & 15 \\
\hline $28-5.9-12$ & R4 & +2.49 & -0.63 & 14 \\
\hline $31-1,36-39$ & $\mathrm{R} 1, \mathrm{R} 2, \mathrm{R} 3$ & +1.21 & -0.33 & 13. \\
\hline $31-2,135-139$ & R6 & +1.23 & -2.61 & 24 \\
\hline $417 \mathrm{~A}-46-3,11-15$ & R7 & +2.15 & -0.46 & 14 \\
\hline
\end{tabular}

${ }^{\text {a }}$ See Table 2.

${ }^{\mathrm{b}}$ Repeated on different areas.

${ }^{c}$ Refers to repeat measurements from other parts of these samples.

altered glass lined with sprays of wispy calcite and blocky spar.

\section{SCANNING ELECTRON MICROGRAPHY (SEM)}

We examined some limestone samples by SEM for evidence of a sedimentary origin. Freshly broken surfaces were gold-coated and viewed with a Cambridge Stereoscan having an EDAX attachment. Samples with an R1 to R5 texture contain numerous nannofossil relicts (Figure 7 and Plate 1). These are almost totally consumed and recrystallized, but a few identifiable forms remained. Most of the relicts are of

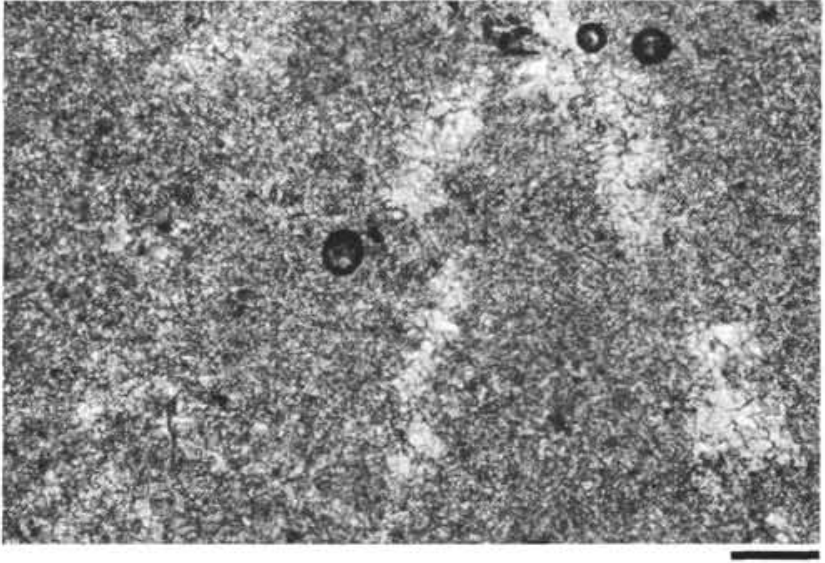

Figure 8. Thin-section micrograph of $R 1=$ stage recrystallization in fine-grained, green limestone, Sample 417D$28-5,6-8 \mathrm{~cm}$. Bar scale 100 microns.

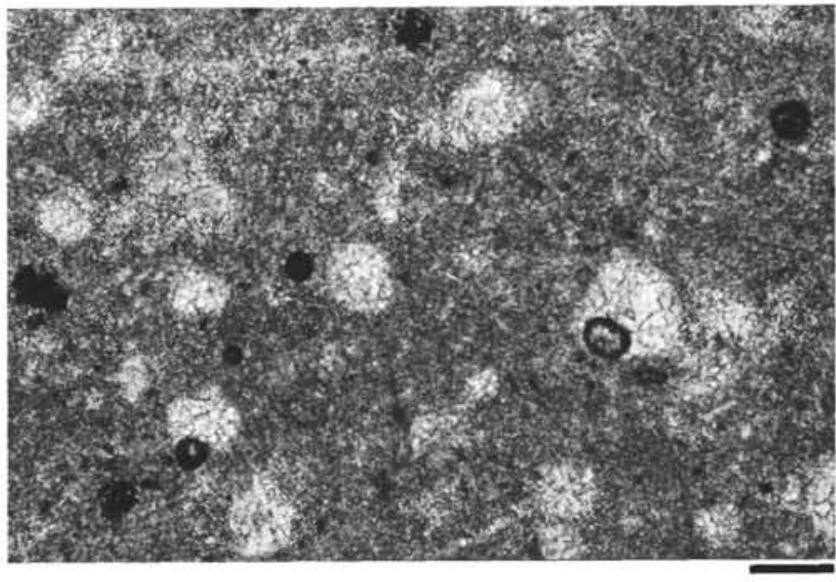

Figure 9. Thin-section micrograph illustrating R2 - stage recrystallization. Many spheroids of sparry calcite as relicts of radiolarians or foraminifers are set in a matrix of fine micritic calcite. A few scattered dark specks are isotropic basalt glass shards. Sample 417D-22-4, 61-65 $\mathrm{cm}$. Bar scale 100 microns.

coccoliths but a few possible calcisphaerulids are present (see Plate 1). We found no obvious radiolarian or foraminiferal relicts. All of the identifiable forms are more or less robust types which have long ranges from Barremian to Aptian (Hans Thierstein, personal communication). These ranges overlap the lower Aptian age from the basal nannofossil chalks at Hole 417D, and one cannot resolve whether the basalt might be significantly older.

Some aspects of the textures in limestones derived from pelagic oozes are noteworthy. Most of the pelagic limestone samples consists of blocky, anhedral calcite crystals. There is little differentiation between cement and particle. The crystal size decreases with distance from devitrified glass fragments (Plate1, Figure 11). Coccoliths have been incorporated into new crystals, obliterating their external features, but commonly retaining some of the more central ornamentation. Perhaps this texture indicates very rapid crystal formation. In the R1- and R2-stage samples, surpris- 


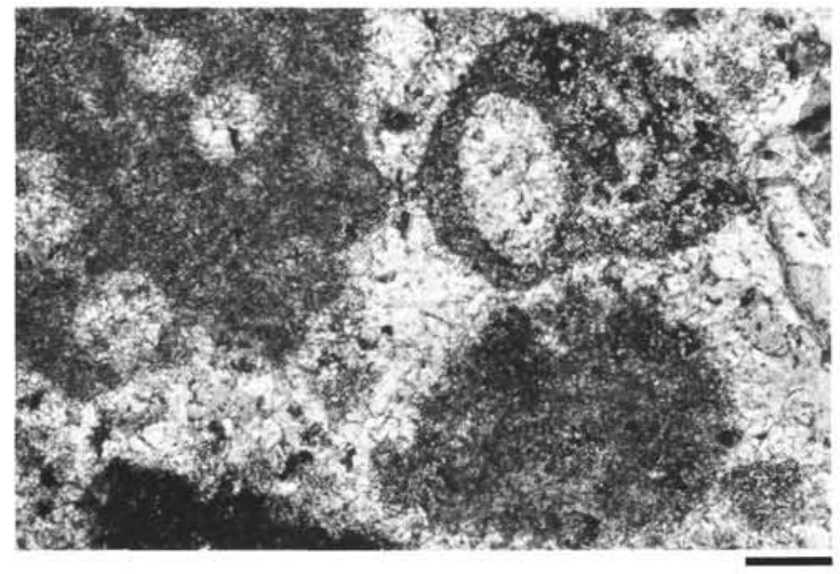

Figure 10. Illustration of R3 - stage recrystallization, showing "structure grumeleuse" texture. Undigested clots of micritic limestone with relict microfossils are surrounded by neomorphic spar. Sample 417D-22-3, 24-27 cm from the border zone between pinkish and light-green limestone. Bar scale 100 microns.

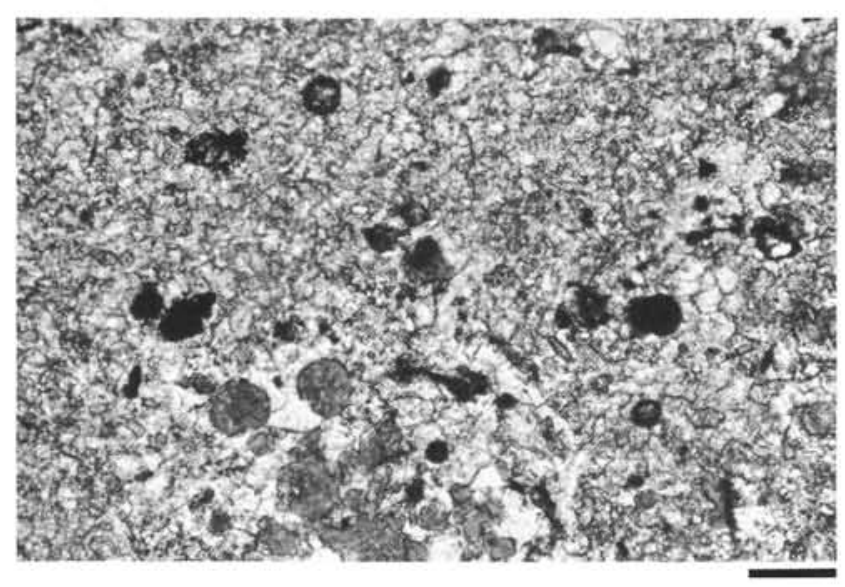

Figure 11. Illustration of R4-stage formation. Fine, completely recrystallized, equigranular neomorphic spar with a few scattered volcanics. Microfossil relicts completely obliterated. Sample 417D-30-6, 23-25 cm. Bar scale 100 microns.

ingly, numerous relict complete coccospheres are embedded in the matrix with an intact arrangement of their placoliths (e.g., Figure 7). This may be evidence of the incorporation of soft ponded oozes into a lava flow, rather than current wafting into spaces which might tend to disaggregate the delicate coccospheres. In green limestones showing more advanced recrystallization (e.g., Sample 417D-28-5, 9-12 $\mathrm{cm}$ ), some faint traces of calcareous nannofossils persist but are rare. Dentation or ornamentation has disappeared. Broken surfaces have a less differentiated appearance, consisting of an interlocking mosaic of anhedral crystals. Original porosity is almost eliminated. In contrast, interpillow limestone fillings of non-pelagic origin, showing R6 and R7 textures, appear in SEM micrographs as equigranular, blocky, calcite crystals with subplanar adjoining faces (Figure 15a).
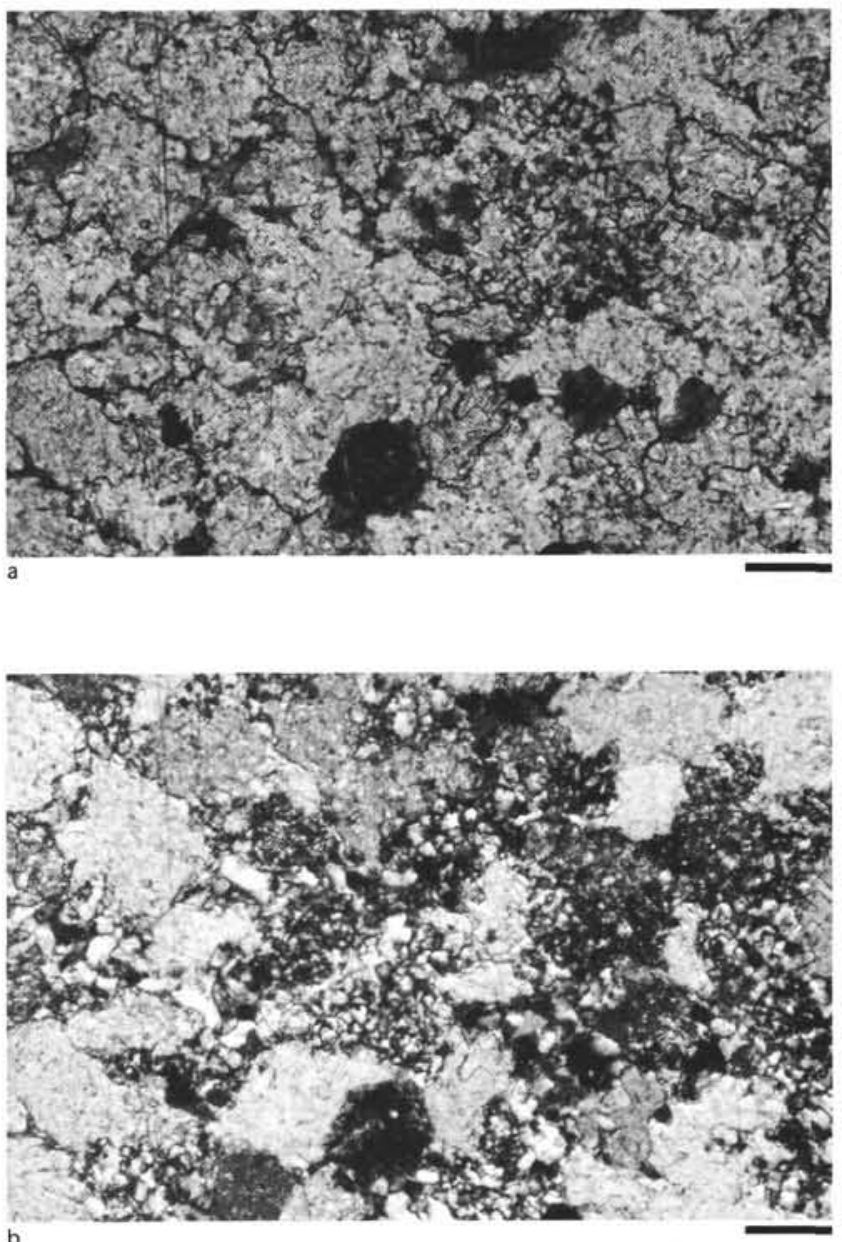

Figure 12. Thin-section micrograph illustrating R5 texture. Interlocking uniform mosaic of sparry neomorphic, anhedral calcite crystals without twinning surround patches of microcrystalline quartz (see $x$-nicols) which may derive from former siliceous microfossils. Basalt glass fragments are isotropic. Sample, 417D-22-7, 10-13 cm. Bar scale 100 microns. A cross-nicols micrograph of the same sample shows the distribution of microcrystalline quartz patches.

A few cases of more prismatic, radiaxial habit occur (Figure $15 b)$.

\section{STABLE-ISOTOPE RATIOS}

The interpillow limestones were analyzed for their stable-isotope content by the traditional method (McCrea, 1950). The gas was analyzed with a Micromass 903 triplecollector mass spectrometer, applying the appropriate correction factors (Craig, 1957). Results are expressed as per mil deviations from the PDB isotopic standard:

$$
\delta=\left[\left(R_{\text {sample }} / R_{\text {standard }}\right)-1\right] \times 10^{3}
$$

where $R={ }^{13} \mathrm{C} /{ }^{12} \mathrm{C}$ or ${ }^{18} \mathrm{O} /{ }^{16} \mathrm{O}$. The precision of measurements, a standard deviation of the mean calculated for replicate analyses, is \pm 0.01 per mil for $\delta^{13} \mathrm{C}$ and \pm 0.04 per mil for $\delta^{18} \mathrm{O}$. The results are listed in Table 3 together with their corresponding recrystallization indices. 


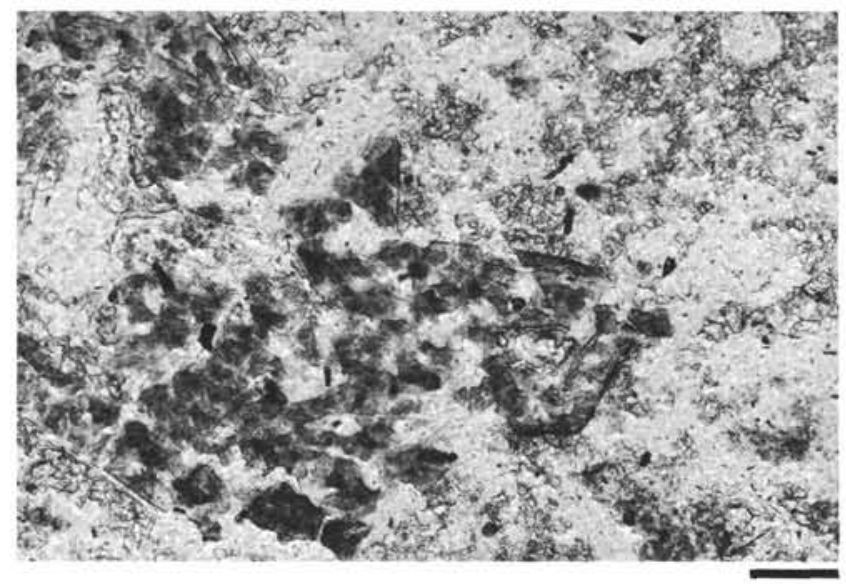

Figure 13. Thin-section micrograph illustrating $R 6$ texture. Large calcite crystals with planar boundaries poikilitically enclose and replace altered glassy pillow margins. Bar scale 100 microns.

A plot of the oxygen- 18 versus carbon- 13 content of the samples in Figure 16 separates the limestones into the two textural categories - recrystallized sediments and alteration by-products. The first group (I) represents the recrystallized sediments and has an average $\delta^{18} \mathrm{O}$ ratio of about 0 per mil. The second group (II) contains limestones with negative $\delta^{18} \mathrm{O}$ ratios. These samples represent the calcite which is a by-product from the submarine alteration of the basaltic glass.

Using the $\delta^{18} \mathrm{O}$ ratios of the carbonates, paleotemperatures of precipitation were calculated and are listed in Table 3 . Computations were made using the paleotemperature equation reported by Shackleton (1973) and a $\delta^{18} \mathrm{O}$ value of -1.2 per mil for preglacial sea water (Shackleton and Kennett, 1975). The temperatures for the recrystallized sediments (R1 through R5) range between $12^{\circ}$ and $15^{\circ} \mathrm{C}$ and probably reflect precipitation at a bottom-water temperature higher than today's. The temperature of Upper Cretaceous bottom waters has been estimated at between $10^{\circ}$ and $15^{\circ} \mathrm{C}$ (Saito and van Donk, 1974). Sample 417D-21-4, 28-30 cm (R0) is a lower Aptian nannofossil chalk cored within 0 to 6 meters of the sediment/basalt interface. Although some isotopic re-equilibration must have occurred during induration, the $\delta^{18} \mathrm{O}$ ratio $(-1.97 \% 0)$ of the chalk continues to indicate the higher temperatures $\left(\sim 20^{\circ} \mathrm{C}\right)$ of the photic zone where the nannofossils bloomed. The isotopic shift of the recrystallized sediments from the interpillow limestones to more positive $\delta^{18} \mathrm{O}$ values than those of the original nannofossil ooze represents an attempt to obtain isotopic equilibrium at lower bottom-water temperatures during the recrystallization process.

The calcite (R6, R7) precipitated during the alteration of the basaltic glass may have formed at higher temperatures, on the order of $24^{\circ}$ to $35^{\circ} \mathrm{C}$. These higher temperatures could be an indicator of hydrothermal activity, which would also account for the possible relict aragonite morphology identified in thin section. On the other hand, submarine
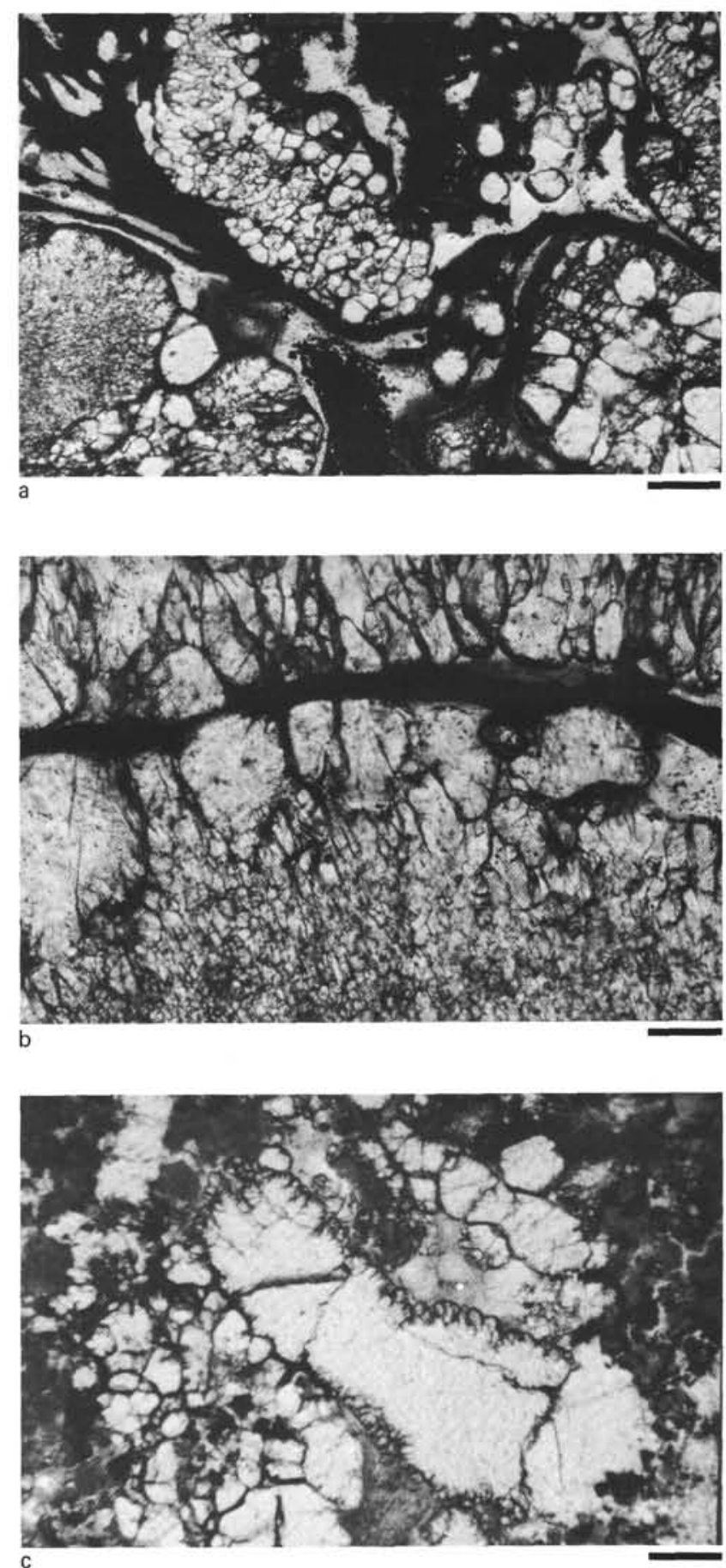

Figure 14. (a) Thin-section micrograph illustrating $R 7$ texture. Cross section of vermiform calcite tubes enclosed in altered basalt glass from a pillow margin. Bar scale is 100 microns. Sample 417D-28-1, 106-110 cm (Piece No. 3). (b) Detail of knobby texture along margins of many crystals. (c) Individual calcite crystal in limestone from near a pillow rind showing a knobby margin. Sample 417D-22-7, 69-71 cm. Bar scale $(10 \times 12.5 \times$ 1.25). Possible relict from aragonite. 

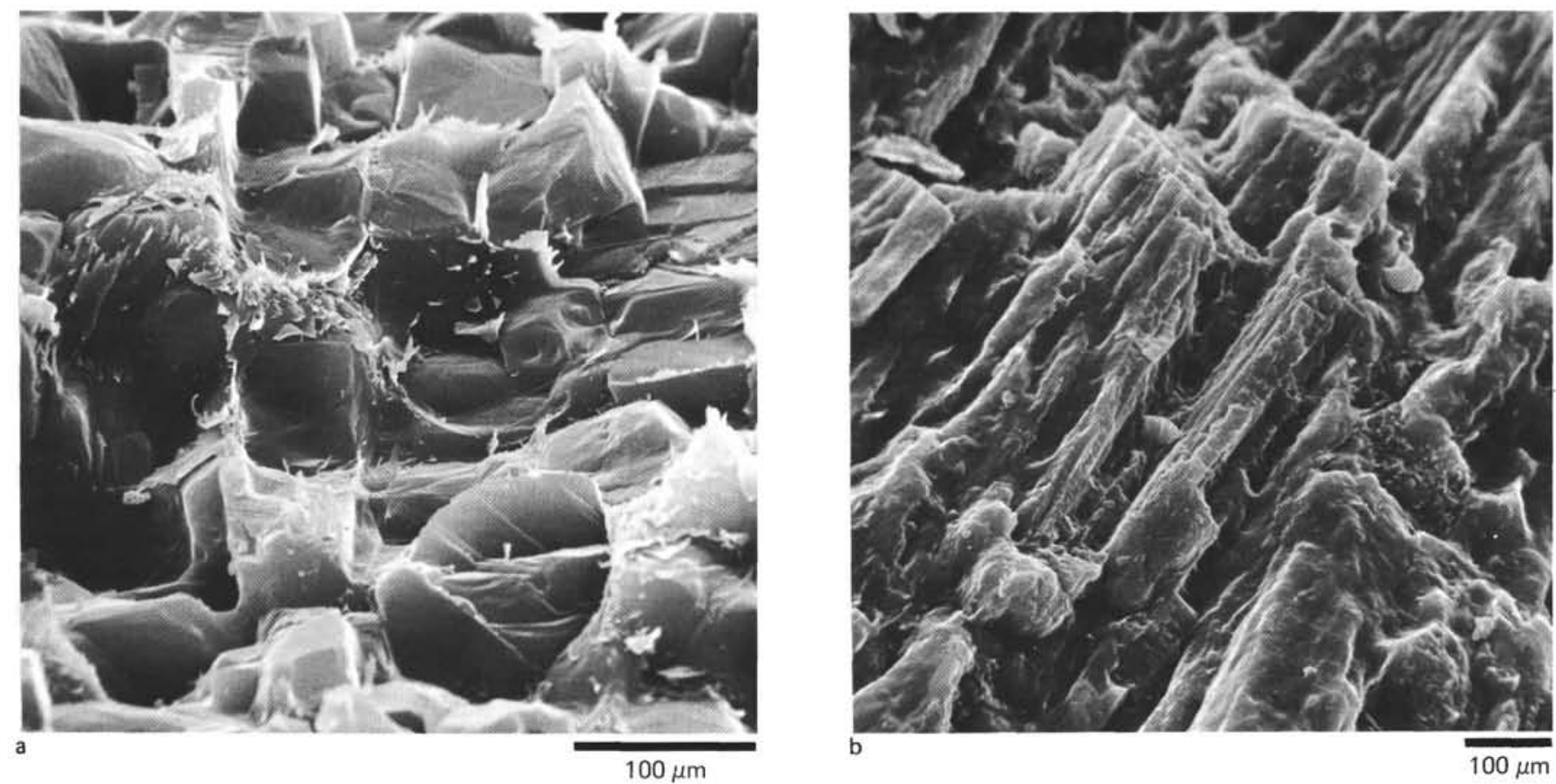

Figure 15. Scanning electron micrograph examples of interpillow calcite derived from basalt alteration. (A) Sample 417D28-1, 106-110 cm (Piece No. 3D) of the knobby, vermiform calcite texture R7. (B) Rare occurrence of wispy, fibrous acicular calcite in brightly colored limestone, Sample 417D-22-1, 16-19 cm (Piece No. 1A).

alteration of basalt to low-temperature minerals depletes the oxygen-18 content of the water participating in the reaction (Lawrence et al., 1975; and Perry et al., 1976). An isotopic alteration of the interstitial waters and subsequent isotopic equilibration with calcite rather than elevated temperatures could then be responsible for the negative oxygen-18 values measured in the carbonates associated with the altered glass.

Anderson and Lawrence (1976) proposed a model for calcite vein genesis which predicts that late-stage alteration of basalts will produce isotopically light water and hence isotopically light calcite. Their model also applies to our recrystallized carbonate sediments as well as to the calcite which is an alteration by-product. The model suggests that early calcite veins are formed at low temperatures in open communication with sea water. These early calcites will have relatively heavy oxygen-18 ratios in comparison to the later calcite veins. The association of the recrystallized sediments from Leg 51 with fresh basaltic glass and their relatively more positive oxygen- 18 content appear to indicate an early-stage recrystallization for this calcite.

The carbonates have variable but positive carbon-13 ratios ranging between +1 and +4 per mille with one exception, Sample 417D-22-1, 16-17 cm. These positive carbon values indicate that the carbonate was precipitated by a process in which isotopic equilibrium with atmospheric carbon dioxide was approached. In other words, the $\mathrm{CO}_{2}$ source was sea water containing dissolved $\mathrm{CO}_{2}$ formerly in equilibrium with atmospheric $\mathrm{CO}_{2}$ or a dissolution of calcareous material with dissolved atmospheric $\mathrm{CO}_{2}$ incorporated into its crystal structure. For example, the calcareous material in the overlying nannofossil chalk has a $\delta^{13} \mathrm{C}$ ratio of +1.55 per mille. On the other hand, the $\delta^{13} \mathrm{C}$ ratio of planktonic organic carbon has an average value of -23 per mille (Sackett et. al., 1965), and oxidation of organic matter in the sediments produces $\mathrm{CO}_{2}$ likewise depleted in carbon-13. The incorporation of $\mathrm{CO}_{2}$ generated by organic decay in the overlying sediments into the calcite of Sample $417 \mathrm{D}-22-1,16-19 \mathrm{~cm}$ explains the rather negative $\delta^{13} \mathrm{C}$ value $(-3.3 \%)$ measured. This sample was cored approximately 1 to 2 meters below the sediment/basalt interface.

It is noteworthy that Sample 417A-46-3, 11-15 cm plots among the recrystallized sediments in Figure 16. This limestone does not have a sedimentary origin but is an alteration by-product within a pillow margin. The pore waters participating in the extensive alteration at Hole 417A did not develop increasingly negative $\delta^{18} \mathrm{O}$ ratios as at Hole 417D but remained in open communication with the marine environment. This example re-emphasizes the importance of the recrystallized sediment as a sealant in the preservation of the glass at Hole 417D.

\section{SUMMARY AND CONCLUSIONS}

From the petrographic and stable-isotopic studies, two distinct types of interpillow limestones were recognized: recrystallized pelagic sediments and by-product calcite from the alteration of basalt. The recrystallized sediment was found in association with the fresh basaltic glass, while the by-product calcite was with the altered basaltic glass. From our observations and measurements, we postulate a tentative sequence of events to explain the formation of the interpillow limestones at Hole 417. Lavas flowed into a depression floored by massive lava and filled with ponded pelagic oozes. Interpillow spaces were blocked by trapped sediments or quickly filled with sediments infiltrated from above. Initial lithification proceeded rapidly, changing oozes into fine, micritic limestone at near ambient sea-water 


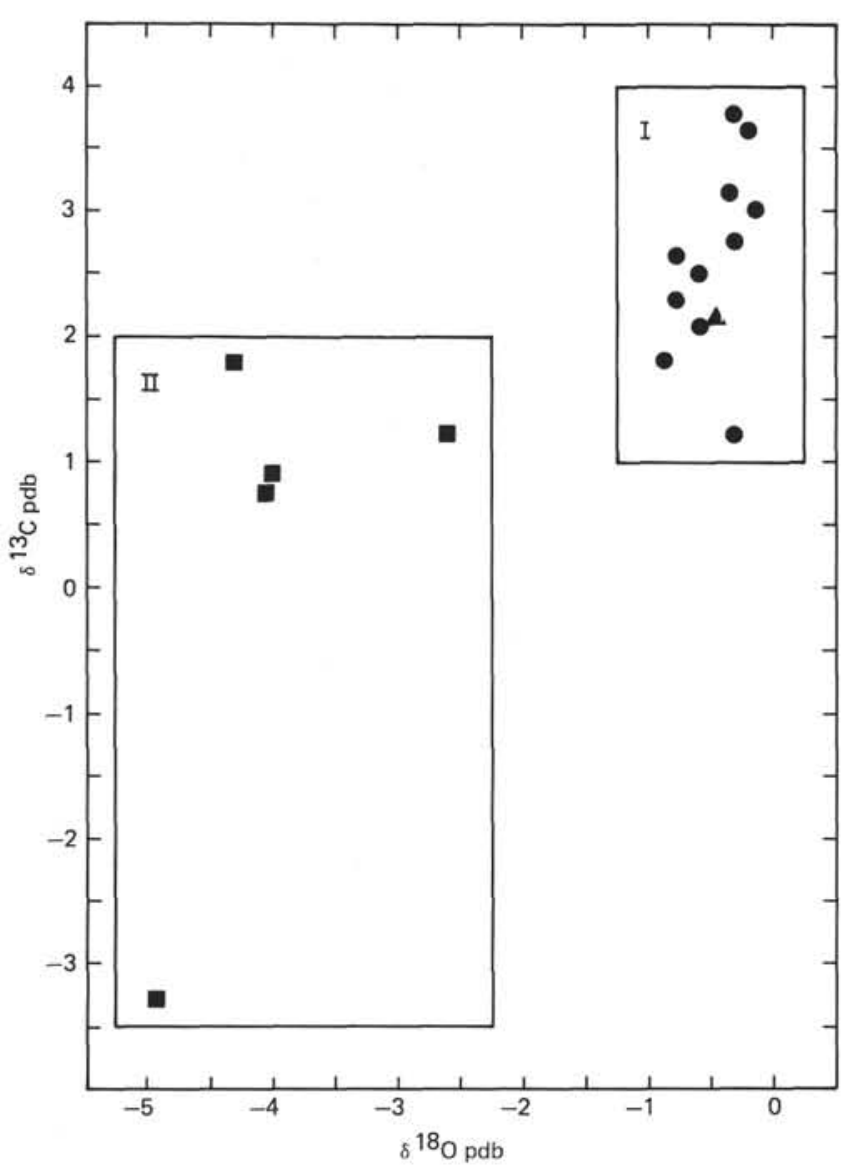

Figure 16. Plot of oxygen-18 versus carbon-13 content for interpillow limestones. Group I are limestones precipitated in an open system from waters with an oxygen-18 content of normal sea water. Group II are limestones precipitated in a closed or semi-closed system from waters that show an oxygen-18 depletion as a result of basalt alteration. The symbols represent the following: recrystallized sediments from Hole $417 \mathrm{D}(\mathrm{O})$ and calcites formed as a by-product of basalt alteration from Holes $417 A(\triangle)$ and $417 D(\square)$.

temperatures. The oxygen-18 content of the recrystallized sediments indicated that the recrystallization process occurred at Late Cretaceous, bottom-water temperatures $\left(10^{\circ}\right.$ to $15^{\circ} \mathrm{C}$ ). The neomorphic nature of this limestone suggests there was enough circulation during lithification to bring in the ions required to fill cavities left by the dissolution of nannofossils. Bottom-water temperatures indicate that lithification of the sediments occurred early and near the sea-water/rock interface. Recrystallization may have been rapid, induced by a perturbation of pore-water alkalinity. This early lithification would account for the preservation of fresh, middle Cretaceous basaltic glass. The recrystallized sediment acted as a sealant reducing the circulation of corrosive sea water around the fresh glass.

Where pelagic oozes were absent and therefore unavailable for lithification at Hole 417D, the unprotected basaltic glass was altered. The incongruent hydrolysis of mafic minerals raised the $\mathrm{pH}$ of the pore solutions, locally as high as 10 to 11 , resulting in the precipitation of calcites in the voids. This calcite, a by-product of basalt alteration, was formed later than the recrystallization of the sediments. We interpret the rather negative oxygen-18 content of the byproduct calcite as a result of isotopic alteration of the interstitial water rather than an indication of hydrothermal activity. The early lithification of interpillow pelagic ooze at Hole 417D greatly restricted sea-water circulation through the pillow piles. Some pillows were not protected by a limestone mantle and their alteration resulted in depletion of the oxygen-18 content of the trapped pore waters. The byproduct calcite was in isotopic equilibrium with these depleted waters; this would account for the relatively depleted oxygen-18 content measured in these calcites. In Hole $417 \mathrm{~A}$, where there was no early-stage lithification, the oxygen-18 values of the by-product calcite indicate paleotemperatures equivalent to those of Hole 417D basal chalks. At Hole $417 \mathrm{~A}$, early-stage lithification did not seal the pillow piles and circulation remained relatively unrestricted. This circulation allowed the alteration of the basaltic glass to proceed without the concurrent development of oxygen-18depleted pore waters.

Previous stable-isotopic studies had indicated that the lithification of carbonate sediments associated with deepsea basalts occurs at bottom-water temperatures rather than elevated temperatures resulting from hydrothermal activity (Lloyd and Hsü, 1972; Garrison et al., 1973; Bonatti et al., 1974; and Bernoulli et al., 1978). In this study, the relatively more negative oxygen-18 contents of the by-product calcites are best explained by the diagenetic model of Anderson and Lawrence (1976) rather than hydrothermal activity. A good example of calcite cementation or recrystallization in deep-sea pillow basalts by thermal metamorphism remains elusive.

The interpillow limestones from Hole 417D are not merely a later-stage breccia infilling but an original feature. Nor are they merely carbonate-cemented sediments but rather a neomorphic transformation of the original pelagic ooze. The dynamic mechanism for the incorporation of pelagic oozes into the basaltic pillows appears to have occurred at the time of lava extrusion. Soft, pelagic ooze was caught up and squeezed between the cooling pillows rolling onto the ponded sediments. Minor baked contacts at the limestone/pillow interface were recognized. Also, a color zonation in the limestones moving away from the pillow margins has a possible thermal origin. This same incorporation mechanism appears to apply to basaltic boulders dredged from the Mid-Atlantic Ridge (Garrison et al., 1973) but may not always be applicable to all limestones intimately associated with deep-sea basalts. Previous studies of sedimentary features of interpillow limestones (e.g., Garrison, 1972) and limestones associated with basaltic breccia (e.g., Bernoulli et al., 1978) indicate that the pelagic sediment had infiltrated into the voids from the overlying ocean floor. Perhaps, the presence of early recrystallized, interpillow limestones which preserve fresh basaltic glass could be used to aid in distinguishing the floors of ancient ridge rift systems from other deep-sea environments.

The reasons for a rapid transformation of pelagic oozes after incorporation into a pillow flow remain obscure. Some aspects from this study include:

1) Direct thermal effects seem unlikely based on oxygen18 composition. 
2) Basalt alteration by-products also seem unlikely in the initial stage, based on the preservation of some basaltic glass. Possibly the trapped oozes served as a nucleation site for fluids moving up from more altered pillows below.

3) Hydrothermal reactions also appear unlikely from textural evidence showing the progressive transformation from the center of pillow interstices to the pillow margins.

\section{ACKNOWLEDGMENTS}

We gladly acknowledge the technical assistance of U. Gerber for photography and $\mathrm{H}$. Franz for scanning electron microscopy. Hans Thierstein kindly identified nannofossils. Thoughtful comments by the reviewers Jim Natland, P. C. de Graciansky, R. Létolle, and Robert Garrison are appreciated. This work was supported by the Swiss National Science Foundation (Grants 2.420-0.75 and 2.777-0.77) and the Swiss Federal Inst. of Technology, ETHZürich.

\section{REFERENCES}

Anderson, T. F. and Lawrence, J. R., 1976. Stable isotope investigations of sediments, basalts, and authigenic phases from Leg 35 cores. In Hollister, C. D., Craddock, C., et al., Initial Reports of the Deep Sea Drilling Project, v. 35: Washington (U.S. Government Printing Office), p. 497-505.

Bathurst, R. G. C., 1975. Carbonate Sediments and Their Diagenesis: Amsterdam (Elsevier), 2nd edition, Developments in Sedimentology Series No. 12.

Bernoulli, D., Garrison, R. E., and McKenzie, J., 1978. Petrology, isotope geochemistry, and origin of dolomite and limestone associated with basaltic breccia, Hole 373A, Tyrrhenian Basin. In Hsü, K., Montadert, L., et al., Initial Reports of the Deep Sea Drilling Project, v. 42, Part 1: Washington (U.S. Government Printing Office), p. 541-558.

Bonatti, E., Emiliani, C., Ferrara, G., Honnorez, J., and Rydell, H., 1974. Ultramafic carbonate breccias from the equatorial Mid-Atlantic Ridge. Mar. Geol., v. 16, p. 83-102.

Craig, H., 1957. Isotopic standards for carbon and oxygen and correction factor for mass-spectrometric analysis of carbon dioxide, Geochim. Cosmochim. Acta., v. 12, p. 133-149.

Garrison, R. E., 1972. Inter- and intra-pillow limestones of the Olympic Peninsula, Washington, J. Geol., v. 80, p. 310-322.

Garrison, R. E., Hein, J. R., and Anderson, T. F., 1973. Lithified carbonate sediment and zeolitic tuff in basalts, Mid-Atlantic Ridge, Sedimentology, v. 20, p. 399-410.
Lawrence, J. R., Gieskes, J. M., and Broecker, W. S., 1975. Oxygen isotope and cation composition of DSDP pore waters and the alteration of layer II basalts, Earth and Planetary Science Letters, v. 27, p. 1-10.

Lloyd, R. M. and Hsü, K. J., 1972. Stable-isotope investigations of sediments from DSDP III cruise to South Atlantic, Sedimentology, v. 19 , p. 45-58.

McCrea, J. M., 1950. The isotopic chemistry of carbonates and a paleotemperature scale, Journal Chem. Phys., v. 18, p. 849 857.

Moore, J. G., 1966. Rate of palagonitization of submarine basalt adjacent to Hawaii, U.S. Geol. Surv. Prof. Paper, v. 550D, p. D163-171.

Perry, E. A., Jr., Gieskes, J. M., and Lawrence, J. R., 1976. Mg, $\mathrm{Ca}$ and $\mathrm{O}^{18} / \mathrm{O}^{16}$ exchange in the sediment-pore water system, Hole 149, DSDP, Geochim. Cosmochim. Acta, v. 40, p. 413423.

Ryan, W. B. F. and Cita, M. B., 1977. Ignorance concerning episodes of ocean-wide stagnation, Mar. Geol., v. 23, p. 197-216.

Sackett, W. M., Eckelmann, W. R., Bender, M. L., and Bé, A. W. H., 1965. Temperature dependence of carbon isotope composition in marine plankton and sediments, Science, v. 148, p. $235-237$.

Saito, T. and van Donk, J., 1974. Oxygen and carbon isotope measurements of Late Cretaceous and Early Tertiary foraminifera, Micropaleontology, v. 20, p. 152-177.

Schlanger, S. O. and Douglas, R. G., 1974. The pelagic oozechalk-limestone transition and its implications for marine stratigraphy. In Hsü, K. J. and Jenkyns, H. C. (Eds.), Pelagic Sediments: On Land and Under the Sea: Oxford (Blackwell Scientific Publications), Spec. Publs. Int. Ass. Sediment., p. 117-148.

Shackleton, N. J., 1973. Attainment of isotopic equilibrium between ocean water and the benthonic foraminifera genus Uvigerina: isotopic changes in the ocean during the last glacial, Colloques Internationaux du C.N.R.S., no. 219, p. 203-209.

Shackleton, N. J. and Kennett, J. P., 1975. Paleotemperature history of the Cenozoic and the initiation of Antarctic glaciation: oxygen and carbon isotope analyses in DSDP Sites 277, 279, and 281. In Kennett, J. P., Houtz, R. E., et al., Initial Reports of the Deep Sea Drilling Project, v. 29: Washington (U.S Government Printing Office), p. 743-755.

Tucholke, B., Vogt, P., et al., 1979. Initial Reports of the Deep Sea Drilling Project, v. 43: Washington (U.S Government Printing Office). 
PLATE 1

Figure 1-9 SEM micrograph examples of the calcareous nannofossil assemblage which occurs as relicts in the pale red part of a limestone specimen. [Sample 417D-311, 36-39 cm (Piece No. 2)] with R1 to R2-stage recrystallization.

1. Possible Lithorhabdus(?).

2. Wetznauria barnesae(?).

3. Podorhabdus dietzmannii.

4. Cretarhabdid(?) shield with some well-defined subhedral calcite crystals.

5. Wetznauria barnesae showing recrystallization rather than overgrowth texture.

6 . Note some minor intergranular porosity remains.

7. Calcisphaerulid pithonella(?).

8. Detail of the wall junction.

9. Coccosphere relict of Wetznauria barnesae(?).

Figures 10-12 SEM micrographs of interpillow limestone not derived from pelagic oozes.

10. Sample 417D-28-1, 106-110 cm (Piece No. 3) from vermiform calcite tubules near pillow margins. Large blocky crystals abut in places with a sheath of altered glass.

11. Sample 417D-31-1, 36-39 cm, showing large calcite crystals rimming an angular, altered volcanic fragment.

12. Close up of smectite clay seams in brightly colored Sample 417D-22-1, 16-19 cm (Piece No. 1). 
PLATE 1
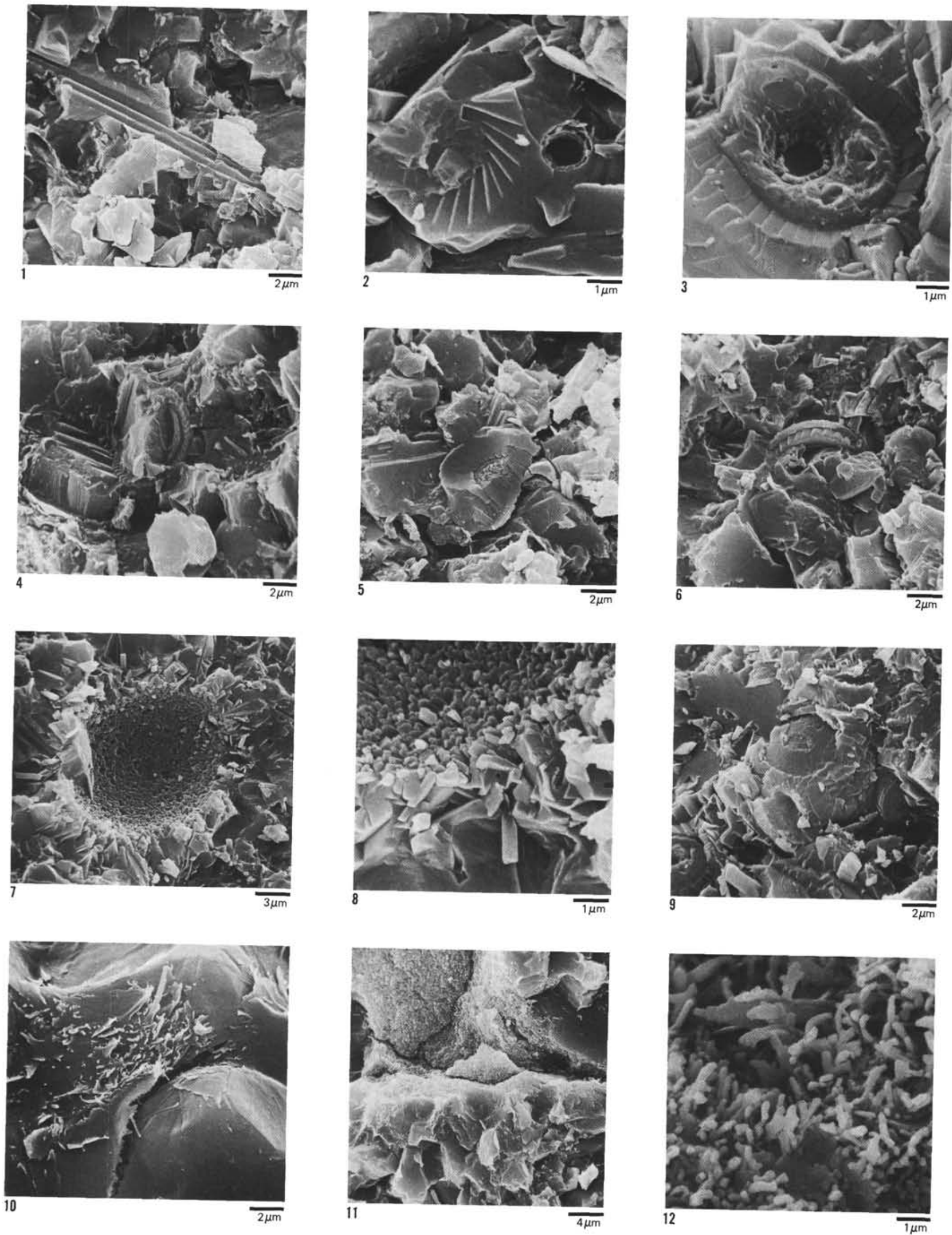